\title{
Evaluation of fatty acids profile of ethyl esters of yellow oleander and groundnut oils as biodiesel feedstock
}

\author{
*Oseni, M. I, Obetta, S. E. and Orukotan, F. V. \\ Department of Mechanical Engineering, University of Agriculture, \\ P. M. B. 2373, Makurdi. *Corresposnding author: mairobo1959@yahoo.com
}

\begin{abstract}
Comparative evaluation of the effect of fatty acids profile on the thermal properties of ethyl esters of yellow oleander (Thevetia peruviana) oil and Groundnut (Arachis hypogiaea) oil as biodiesel feedstock was carried out. Chemo-physical properties of the oils and their fatty acid profile were determined. Ethyl esters of the oils were obtained by transesterification using ethanol with potassium hydroxide as catalyst. Chemo-physical properties and fatty acids profile were determined for the biodiesel produced. Results showed that the chemo-physical properties obtained for the ethyl ester of yellow oleander oil such as flash point $\left(48.67^{\circ} \mathrm{C}\right)$, fire point $\left(86.33^{\circ} \mathrm{C}\right)$, cloud point $\left(12.3^{\circ} \mathrm{C}\right)$, pour point $\left(2.33^{\circ} \mathrm{C}\right)$ and free fatty acids $(0.65 \%)$ were consistent with ASTM stipulated standards for fuel grade biodiesel. The fatty acids for yellow oleander were predominantly $7.337 \%$ stearic acid $(2,696.12 \mathrm{~J} / \mathrm{kg}), 18.618 \%$ palmitic acid $(2384.76 \mathrm{~J} / \mathrm{kg}), 49.615 \%$ Oleic acid $(2657.4 \mathrm{~J} / \mathrm{kg}$ ) and $14.22 \%$ linoleic acid. The saturated fatty acids were capable of readily releasing their heat content during combustion. Groundnut oil gave similar result except $66.15 \%$ oleic acid which put it ahead of yellow oleander's $49.61 \%$. On the basis of thermal properties, groundnut oil was better but the drawback as biodiesel feedstock lies in its high free fatty acids and the pressure on it as a staple crop. Use of yellow oleander biodiesel would reduce this pressure and extend the use of this ornamental crop.
\end{abstract}

Keywords: Evaluation, fatty acids, thermal properties, yellow oleander, groundnut oil.

\section{INTRODUCTION}

The depletion of the world petroleum reserves and the increased environmental threat and security concerns has stimulated the search for alternative sources to petroleum-based fuels. Because of closer properties to fossil diesels, its renewability, higher energy efficiency, direct usage in diesel equipment with little or no modifications, environmental friendliness, reduction of tailpipe emissions, nontoxicity and bio degradability, biodiesel fuel (fatty acid ethyl and methyl esters) from vegetable oil feed stocks is considered as the best candidate for diesel fuel suitable in diesel engines (Kusdiana et al 2004, Gerpen, 2004, Gerpen et al 2004 and World Watch Institute, 2008). Biodiesel as an alternative fuel for fuel engines has met the four critical criteria for a viable alternative fuel that includes the possession of superior environmental benefits, economic competitiveness, production of sufficient quantities and mass energy gains (World Watch Institute, 2008, Manuel, 2007 and Vairavan et al 2010). Because all vegetable oils are potential biodiesel fuel, energy specialists are interested in oil seeds that will best satisfy this need and be abundant, while not competing with human consumption needs (Schmidt, 2007). Such oil seeds will preferably be non-edible, have potentials for effective production of ethyl and methyl esters.

As the capacity of biodiesel production increases, there would be a corresponding increase in demand for oil and fats. In the United States of America (USA) for instance, soybean oil is favorable because production surpluses are available that can easily be processed into biodiesel (Ibiyemi, 2003). In Brazil and some Asian countries, Jatropha curcas is preferred because of its non-edibility, high percentage oil content and wide geographic and climatic spread.

This research paper is interested in the analysis of the effects of fatty-acid profile on the thermal properties of biodiesel from Yellow oleander (Thevetia peruviana) and Groundnut (Arachis hypogiaea) oil seeds. The former is an energy crop available in the tropical and semiarid zones of Nigeria while the latter is available and easily cultivated in the semiarid zones of the country. 
Yellow Oleander (Thevetia peruviana) oil seeds contain about $60-65 \%$ oil content for biodiesel production and good alternative protein source (37\%) for live stock feeds (Ibiyemi et al 2006). It thrives well in all the climatic and vegetation belts of Nigeria. Groundnuts on the other hand, are used as food and are exported on a large scale as an Oil-seed. Groundnut oil is edible and the cake which is left after the oil is removed is used for livestock feeding. It grows well in the northern part of the country, (e.g Kano) with temperature range of $25^{\circ} \mathrm{C}-30^{\circ} \mathrm{C}$, and rainfall of about $70 \mathrm{~cm}-100 \mathrm{~cm}$ per annum.

Oil can be extracted from yellow oleander and groundnuts by mechanical, solvent and manual extraction with solvent extraction preferred when oil is extracted in commercial quantity (World Watch Institute, 2008).

Many vegetable oils have fuel properties similar to conventional diesel fuel. In the study of the chemo physical properties of oils, reference is normally made to physical and thermal properties such as melting point, Flash point, Calorific value, Density, Cloud point, Kinematics Viscosity, Boiling point, cetane number, heat value and specific gravity among others.

Fatty-Acids profile of any vegetable oil determines the chemical and physical properties of such oil. Transesterification as the major process of Biodiesel production involves the separation of the fatty acids (FA) components of the vegetable oil (Triglyceride) by the catalytic reaction of methanol or ethanol with sodium hydroxide $(\mathrm{NaOH})$ or potassium hydroxide $(\mathrm{KOH})$ as catalyst. The methyl or ethyl esters formed from the fatty-acids end is the biodiesel while glycerin is a coproduct (World Watch Institute, 2008, Vairavan et al 2010 and Kinasi, 2003). The type of methyl or ethyl ester formed is dependent on the fatty acid component(s) of the vegetable oil. Determination of the fatty acid profile of vegetable oils and biodiese establishes the level of saturation or otherwise of the fatty acids in the oil and biodiesel and the effect on the thermal behavior of the biodiesel.

This research paper is aimed at determining the effect of fatty-acid profile on the thermal properties of biodiesel from yellow oleander and groundnut oil seeds as biodiesel feedstock.

\section{MATERIALS AND METHODS}

Oil was extracted from yellow oleander seeds obtained in Makurdi by mechanical expression using a screw press as described by McCabe et al (1987) while groundnut oil was obtained from the open market in Makurdi.

Chemo-physical and thermal analysis carried out on oil samples included specific gravity, flash point, fire point, cloud point, pour point, free fatty acids and average heat value. Free fatty acids content was determined as described by David (1970), flash and fire points (ASTM D-92), moisture content, pour point (ASTM D-97) and viscosity (IP71/ASTM D-445) was determined as described by Baker (1984).

The oils were transesterified using ethanol in the presence of potassium hydroxide. The quantity of reactants used for reaction were $750 \mathrm{ml}$ of oil to $250 \mathrm{ml}$ of ethanol for $5 \mathrm{~g}$ of potassium hydroxide as catalyst for tranesterification of yellow oleander oil and $750 \mathrm{ml}$ of oil to $250 \mathrm{ml}$ of ethanol for $8 \mathrm{~g}$ of potassium hydroxide as catalyst for tranesterification of groundnut oil. Excess ethanol in the reaction was to ensure total conversion of oil to biodiesel. The reaction was carried out in an enclosed vessel, with temperature just above the room temperature $\left(32^{\circ} \mathrm{C}\right)$ . On settling, the biodiesel which which had lower specific gravity and yellow in colour settled on top while the glycerol settles below in the settling tank. The biodiesel obtained for the two oils was washed and dried as described by Kinast (2003). Samples of the biodiesel obtained were also analyzed for chemophysical and thermal properties as was done to the oil samples. Fatty acid composition profile of the oils and biodiesel was determined as described by Christie (1989) using liquid-gas chromatography.

Using Liquid-Gas chromatography, the percentage weight of each acid in the fatty acids composition was obtained and used to determine contribution of each acid to the overall heat of consumption of the fatty acids in the oil and biodiesel samples.

\section{RESULTS AND DISCUSSION}

Chemo-Physical Properties: Table 1 shows the chemo-physical and thermal properties of the oil samples. It was observed that the esterification of the two vegetable oils sharply reduced the values of the viscosity measured.

The suitability of vegetable oil as biodiesel results from their molecular structure and high energy content. Yellow oleander oil had high saturated fatty compounds than groundnut oil which showed that yellow oleander oil has high cetane number and short ignition delay time. 
Am. J. Sci. Ind. Res., 2012, 3(2): 62-68

Table 1:- Chemo-Physical Properties of Oil and Fuel Samples

\begin{tabular}{|lcccc|}
\hline & Oil & & \multicolumn{2}{c|}{ Biodiesel } \\
& Yellow Oleander & Groundnut & Yellow Oleander & Groundnut \\
\hline Kinematic Viscosity, $40^{\circ} \mathrm{C}$ & 40.42 & 41.6 & 28.67 & 19.3 \\
Kinematic Viscosity, $100^{\circ} \mathrm{C}$ & 17.06 & 20.5 & 8.06 & 6.73 \\
Heat Value, Kcal & - & - & 9859.2 & 9508.8 \\
Cloud Point, ${ }^{\circ} \mathrm{C}$ & 14 & 9 & 12.3 & 7.3 \\
Pour Point, ${ }^{0} \mathrm{C}$ & 2 & 1 & 2.33 & 4 \\
Flash Point, ${ }^{0} \mathrm{C}$ & 190 & 271 & 48.67 & 49 \\
Fire Point, ${ }^{\circ} \mathrm{C}$ & 250 & 280 & 86.33 & 53.3 \\
Specific Gravity & 0.905 & 0.892 & 0.893 & 0.787 \\
FFA, \% & 1.96 & 9.93 & 0.65 & 3.7 \\
Moisture, \% & 0.09 & 0.08 & 0.55 & 0.13 \\
\hline
\end{tabular}

Conventional diesel $=10,825 \mathrm{KCal}$

The measured flash points of the vegetable oils and their ethyl esters (Biodiesel) were well within the stipulated requirement of A S T M standard of $300^{\circ} \mathrm{C}$ and $75^{\circ} \mathrm{C}$ respectively. The flash point and fire point of biodiesel produced from both vegetable oils yellow oleander and groundnut $\left(48.67^{\circ} \mathrm{C}, 86.33^{\circ} \mathrm{C}, 48^{\circ} \mathrm{C}\right.$ and $53.3^{\circ} \mathrm{C}$ respectively), were relatively lower than that of the fresh vegetable oils possibly because of esterification that took place. The specific gravity of the oil and their ethyl ester were within the stipulated values for fuel grade biodiesel and conventional diesel (0.90).

There was appreciable reduction in percentage free fatty acid of the biodiesels as a high proportion of the free fatty acid was neutralized by potassium hydroxide during transesterification (Vairavan et al 2010).

Fatty Acid Compositional Profile: In Table 1, it was observed that groundnut oil had higher free fatty acid composition (9.93\%) which suggested that it was not economical for the production of Biodiesel as it would require pretreatment such as alkaline treatment capable of increasing cost of production of biodiesel. On the other hand, yellow oleander had a relatively low free fatty acid composition (1.96\%) making it a good candidate for biodiesel production.

The fatty acid compositional profile of yellow oleander and groundnut oil and their ethyl esters are shown in Tables 2-5. In Table 2 various acids making up the fatty acids are shown. Yellow oleander oil contained predominantly Stearic acid $(6.23 \%)$, Palmitic acid $(17.02 \%)$, Oleic acid (41.91\%), Linoleic acid (11.89\%), Linolenic acid (1.15\%) and Arachidic acid (1.82). These components have various molecular weights, melting points, boiling points and heat of combustion. Stearic acid with heat of combustion of $2696.12 \mathrm{~J} / \mathrm{Kg}$ contributed significantly to the overall heat of combustion of the oil. However, it was only $6.238 \%$ of the total fatty acid composition of the oil. But oleic acid with heat of combustion of $2657.4 \mathrm{~J} / \mathrm{Kg}$ and composition of $41.91 \%$ contributed most to the overall heat of combustion of the oil. Palmitic acid with a composition of $17.02 \%$ and heat of combustion of $2384.76 \mathrm{~J} / \mathrm{Kg}$ was also contributory to the heat of combustion of the oil. Linoleic acid with a composition of $11.894 \%$ has 18 carbon atoms and a double bond. This made this acid the only acid with double bond (unsaturated). Unsaturated fatty acid would not readily release its heat content during the combustion of the oil (Christie, 1989, Gerpen, 2004 and Vairavan et al 2010). Since it is only $11.89 \%$ of the fatty acid composition, its effect may be minimal.

Over $85 \%$ of the fatty acids composition of the oil were saturated and therefore would readily release their heat content during combustion; hence the oil is containing saturated fatty Acids with high heat of combustion. The boiling points of the fatty Acids identified were high (about $300^{\circ} \mathrm{C}$ ). Hence the fatty Acids had low volatility thereby making the oil suitable for storage and for further processing into biodiesel. The fatty Acids identified were suitable for processing into biodiesel (Gerpen et al 2004).

Table 3 shows the Fatty Acids profile for the biodiesel produced from yellow oleander. The predominant components of the Fatty Acids were Stearic Acid, Palmitic Acid, Oleic Acid, Linoleic Acid, Linolenic Acid and Arachidic Acid. 
Am. J. Sci. Ind. Res., 2012, 3(2): 62-68

Table 2: Fatty Acid Profile of Yellow Oleander Oil

\begin{tabular}{|l|c|c|c|c|c|}
\hline $\begin{array}{l}\text { Fatty Acids } \\
\text { (C:H) }\end{array}$ & $\begin{array}{c}\text { \% Weight } \\
\text { (present work) }\end{array}$ & $\begin{array}{c}\text { Molecular } \\
\text { weight }\end{array}$ & $\begin{array}{c}\text { Melting point } \\
{ }^{\circ} \mathrm{C}\end{array}$ & Boiling point ${ }^{\circ} \mathrm{C}$ & $\begin{array}{c}\text { Heat of Combustion } \\
\mathrm{J} / \mathrm{kg}\end{array}$ \\
\hline Butyric Acid (5:0) & 0.000048 & - & - & - & - \\
\hline Caproic Acid (6:0) & 0.000046 & - & - & - & - \\
\hline Caprylic Acid(8:0) & 0.000031 & 144.22 & 16.5 & 239 & - \\
\hline Capric Acid (10:0) & 0.000083 & 172.27 & 31.5 & 270 & 1453.07 \\
\hline Lauric Acid (12:0) & 0.007322 & 200.32 & 44 & 131 & 1763.25 \\
\hline Myristic Acid (14:0) & 0.025957 & 228.38 & 58 & 250.5 & 2073.91 \\
\hline Palmitic Acid (16:0) & 17.02448 & 256.43 & 63 & 350 & 2384.76 \\
\hline Palmitoleic Acid (16:1) & 0.293255 & - & - & - & - \\
\hline Oleic Acid (18:1) & 41.905726 & 282.47 & 16 & 286 & - \\
\hline Linoleic Acid (18:2) & 11.893577 & 280.45 & -5 & 229.30 & - \\
\hline Linolenic Acid (18:3) & 1.152076 & 278.44 & -11 & $230-2$ & - \\
\hline Arachidic Acid (20:0) & 1.818016 & - & - & - & - \\
\hline Behenic Acid (22:0) & 0.000081 & - & - & - & - \\
\hline Erucic Acid (22:1) & 0.000054 & 338.58 & $33-4$ & 265 & - \\
\hline Lignoceric (24:0) & 0.001875 & - & - & 360 & - \\
Stearic Acid (18;0) & 6.237729 & 284.48 & 71 & & \\
& & & & & \\
\hline
\end{tabular}

Table 3. Table 3 Fatty Acid Profile of Yellow Oleander Biodiesel (B100)

\begin{tabular}{|c|c|c|c|c|c|}
\hline $\begin{array}{l}\text { Fatty Acids } \\
(\mathrm{C}: \mathrm{H})\end{array}$ & $\begin{array}{l}\text { \% Weight } \\
\text { (present work) }\end{array}$ & $\begin{array}{l}\text { Molecular } \\
\text { weight }\end{array}$ & $\begin{array}{l}\text { Melting point } \\
{ }^{0} \mathrm{C}\end{array}$ & Boiling point ${ }^{\circ} \mathrm{C}$ & $\begin{array}{l}\text { Heat of } \\
\text { combustion } \mathrm{J} / \mathrm{kg}\end{array}$ \\
\hline $\begin{array}{l}\text { Butyric Acid } \\
(5: 0)\end{array}$ & 0.000062 & - & - & - & - \\
\hline $\begin{array}{l}\text { Caproic Acid } \\
(6: 0)\end{array}$ & 0.000059 & - & - & - & - \\
\hline $\begin{array}{l}\text { Caprylic } \\
(8: 0)\end{array}$ & 0.000040 & 144.22 & 16.5 & 239 & - \\
\hline $\begin{array}{l}\text { Capric Acid } \\
(10: 0)\end{array}$ & 0.000105 & 172.27 & 31.5 & 270 & 1453.07 \\
\hline $\begin{array}{l}\text { Lauric } \\
(12: 0)\end{array}$ & 0.076406 & 200.32 & 44 & 131 & 1763.25 \\
\hline $\begin{array}{l}\text { Myristic } \\
(14: 0)\end{array}$ & 0.072156 & 228.38 & 58 & 250.5 & 2073.91 \\
\hline $\begin{array}{l}\text { Palmitic } \\
(16: 0)\end{array}$ & 14.133939 & 256.43 & 63 & 350 & 2384.76 \\
\hline $\begin{array}{l}\text { Palmitoleic } \\
(16: 1)\end{array}$ & 0.141086 & - & - & - & - \\
\hline $\begin{array}{l}\text { Oleic } \\
(18: 1)\end{array}$ & 58.103102 & 282.47 & 16 & 286 & 2657.4 \\
\hline $\begin{array}{l}\text { Linoleic } \\
(18: 2)\end{array}$ & 19.495762 & 280.45 & -5 & 229.30 & - \\
\hline $\begin{array}{l}\text { Linolenic } \\
(18: 3)\end{array}$ & 0.088201 & 278.44 & -11 & $230-2$ & - \\
\hline $\begin{array}{l}\text { Arachidic } \\
(20: 0)\end{array}$ & 1.577912 & - & - & - & - \\
\hline $\begin{array}{l}\text { Behenic } \\
(22: 0)\end{array}$ & 0.000104 & - & - & - & - \\
\hline $\begin{array}{r}\text { Erucic } \\
(22: 1)\end{array}$ & 0.449267 & 338.58 & $33-4$ & 265 & - \\
\hline $\begin{array}{l}\text { Lignoceric } \\
(24: 0)\end{array}$ & 2.663248 & & & & \\
\hline Stearic Acid $(18 ; 0)$ & 3.195084 & 284.48 & 71 & 360 & 2696.12 \\
\hline
\end{tabular}


Stearic Acid with a percentage composition of $7.34 \%$ and heat of combustion of 2,696.12 J/kg was saturated with 18 carbon atoms. The heat of combustion was a significant contribution to the heat of combustion of the oil. Palmitic Acid, also a Saturated acid, had a composition of $18.62 \%$ and heat of combustion of $2384.76 \mathrm{~J} / \mathrm{kg}$; its contribution to the heat of combustion of the oil was also significant. However, most significant was the contribution of Oleic Acid with a composition of $49.62 \%$ and heat of combustion of $2657.4 \mathrm{~J} / \mathrm{kg}$. Oleic Acid with a single bound and saturation level contributed immensely to the performance of the biodiesel.

The fatty acid composition of the biodiesel from yellow oleander oil would effectively constitute a fuel that would replace conventional petroleum diesel in energy applications. The heat of combustion of the biodiesel from yellow oleander oil was well suited to compression ignition engine.

The same fatty acid distribution was observed for groundnut oil and its ethyl ester in Tables 4 and 5 . However, the heat of combustion in both cases were higher than that of yellow oleander and its ethyl ester as indicated by the oleic acid content of $58.1 \%$ and $66.15 \%$ for groundnut oil and its ethyl ester respectively. On the basis of ease of combustion, groundnut oil and its ethyl ester are better but the drawback as biodiesel feedstock lies in its high free fatty acid and the pressure on it as a staple crop (World Watch Institute, 2008, Manuel, 2007 and Vairavan et al 2010).

\section{Table 4: Fatty Acid Profile of Groundnut oil}

\begin{tabular}{|c|c|c|c|c|c|}
\hline $\begin{array}{l}\text { Fatty Acids } \\
(\mathrm{C}: \mathrm{H})\end{array}$ & $\begin{array}{l}\text { \% Weight } \\
\text { (present work) }\end{array}$ & $\begin{array}{l}\text { Molecular } \\
\text { weight }\end{array}$ & $\begin{array}{l}\text { Melting point } \\
{ }^{\circ} \mathrm{C}\end{array}$ & Boiling point ${ }^{\circ} \mathrm{C}$ & $\begin{array}{l}\text { Heat of combustion } \\
\mathrm{J} / \mathrm{kg}\end{array}$ \\
\hline $\begin{array}{l}\text { Butyric Acid } \\
(5: 0)\end{array}$ & 0.000062 & - & - & - & - \\
\hline $\begin{array}{l}\text { Caproic Acid } \\
(6: 0)\end{array}$ & 0.000059 & - & - & - & - \\
\hline $\begin{array}{l}\text { Caprylic } \\
(8: 0)\end{array}$ & 0.000040 & 144.22 & 16.5 & 239 & - \\
\hline $\begin{array}{l}\text { Capric Acid } \\
(10: 0)\end{array}$ & 0.000105 & 172.27 & 31.5 & 270 & 1453.07 \\
\hline $\begin{array}{c}\text { Lauric } \\
(12: 0)\end{array}$ & 0.076406 & 200.32 & 44 & 131 & 1763.25 \\
\hline $\begin{array}{l}\text { Myristic } \\
(14: 0)\end{array}$ & 0.072156 & 228.38 & 58 & 250.5 & 2073.91 \\
\hline $\begin{array}{l}\text { Palmitic } \\
(16: 0)\end{array}$ & 14.133939 & 256.43 & 63 & 350 & 2384.76 \\
\hline $\begin{array}{l}\text { Palmitoleic } \\
(16: 1)\end{array}$ & 0.141086 & - & - & - & - \\
\hline $\begin{array}{l}\text { Oleic } \\
(18: 1)\end{array}$ & 58.103102 & 282.47 & 16 & 286 & 2657.4 \\
\hline $\begin{array}{l}\text { Linoleic } \\
(18: 2)\end{array}$ & 19.495762 & 280.45 & -5 & 229.30 & - \\
\hline $\begin{array}{l}\text { Linolenic } \\
(18: 3)\end{array}$ & 0.088201 & 278.44 & -11 & $230-2$ & - \\
\hline $\begin{array}{l}\text { Arachidic } \\
(20: 0)\end{array}$ & 1.577912 & - & - & - & - \\
\hline $\begin{array}{l}\text { Behenic } \\
(22: 0)\end{array}$ & 0.000104 & - & - & - & - \\
\hline $\begin{array}{l}\text { Erucic } \\
(22: 1)\end{array}$ & 0.449267 & 338.58 & $33-4$ & 265 & 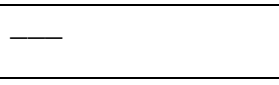 \\
\hline $\begin{array}{l}\text { Lignoceric } \\
(24: 0) \\
\text { Stearic Acid }(18 ; 0)\end{array}$ & $\begin{array}{l}2.663248 \\
3.195084\end{array}$ & 284.48 & 71 & 360 & 2696.12 \\
\hline
\end{tabular}


Am. J. Sci. Ind. Res., 2012, 3(2): 62-68

Table 5: Free Fatty Acid Profile of Groundnut oil Biodiesel (B100)

\begin{tabular}{|c|c|c|c|c|c|}
\hline $\begin{array}{l}\text { Fatty Acids } \\
(\mathrm{C}: \mathrm{H})\end{array}$ & $\begin{array}{l}\text { \% Weight (present } \\
\text { work) }\end{array}$ & Molecular weight & $\begin{array}{l}\text { Melting point } \\
{ }^{0} \mathrm{C}\end{array}$ & $\begin{array}{l}\text { Boiling point } \\
{ }^{0} \mathrm{C}\end{array}$ & $\begin{array}{l}\text { Heat of combustion } \\
\mathrm{J} / \mathrm{kg}\end{array}$ \\
\hline $\begin{array}{l}\text { Butyric Acid } \\
(5: 0)\end{array}$ & 0.000044 & - & - & - & - \\
\hline $\begin{array}{l}\text { Caproic Acid } \\
(6: 0)\end{array}$ & 0.000041 & - & - & - & - \\
\hline $\begin{array}{l}\text { Caprylic } \\
(8: 0)\end{array}$ & 0.000027 & 144.22 & 16.5 & 239 & - \\
\hline $\begin{array}{l}\text { Capric Acid } \\
(10: 0)\end{array}$ & 0.000074 & 172.27 & 31.5 & 270 & 1453.07 \\
\hline $\begin{array}{r}\text { Lauric } \\
(12: 0) \\
\end{array}$ & 0.054015 & 200.32 & 44 & 131 & 1763.25 \\
\hline $\begin{array}{l}\text { Myristic } \\
(14: 0)\end{array}$ & 0.050773 & 228.38 & 58 & 250.5 & 2073.91 \\
\hline $\begin{array}{l}\text { Palmitic } \\
(16: 0)\end{array}$ & 8.302172 & 256.43 & 63 & 350 & 2384.76 \\
\hline $\begin{array}{l}\text { Palmitoleic } \\
(16: 1)\end{array}$ & 0.098467 & - & - & - & - \\
\hline $\begin{array}{l}\text { Oleic } \\
(18: 1)\end{array}$ & 66.152886 & 282.47 & 16 & 286 & 2657.4 \\
\hline $\begin{array}{c}\text { Linoleic } \\
(18: 2)\end{array}$ & 17.338819 & 280.45 & -5 & 229.30 & - \\
\hline $\begin{array}{l}\text { Linolenic } \\
(18: 3)\end{array}$ & 0.068889 & 278.44 & -11 & $230-2$ & - \\
\hline $\begin{array}{l}\text { Arachidic } \\
(20: 0)\end{array}$ & 1.370734 & - & - & - & - \\
\hline $\begin{array}{c}\text { Behenic } \\
(22: 0)\end{array}$ & 0.000099 & - & - & - & - \\
\hline $\begin{array}{l}\text { Erucic } \\
(22: 1)\end{array}$ & 0.341437 & 338.58 & $33-4$ & 265 & - \\
\hline $\begin{array}{l}\text { Lignoceric } \\
(24: 0)\end{array}$ & & & & & \\
\hline Stearic Acid $(18 ; 0)$ & 2.262583 & 284.48 & 71 & 360 & 2696.12 \\
\hline
\end{tabular}

\section{CONCLUSION}

The fatty acid profiles of biodiesel from Yellow oleander (Thevetia peruviana) oil and groundnut(Arachis hypogiaea) oil were determined to predict the effect of change in fatty acids composition on their thermal properties as often encountered in cultivation of the oil seeds or processing of the oils. The saturation of the major component of fatty acids such as oleic acid, palmitic acid and stearic acid makes yellow oleander and groundnut oil suitable for storage during processing into biodiesel.

Yellow oleander feed stock have low free fatty acid content $(<1 \%)$ which is close to the required standard $(0.5 \%)$ for biodiesel production compared to groundnut oil with high free fatty acid (9.93\%). Increased use of yellow oleander oil (a horticultural crop) as feedstock for biodiesel production will boost upstream agricultural activities and provide employment. The comparison of groundnut and yellow oleander oils as biodiesel feedstock showed that yellow oleander was capable of reducing the current pressure on groundnut oil as food staple and biodiesel feedstock.

\section{REFERENCES}

Baker, A. E(1984) Lubricant Properties and Test Methods Handbook of Lubrication, Theory and Practice of Tribology, Vol. I, Ed. E. R. Booser, CRC Press, (1984), pp.481-515

Christie, W. W. (1989) Gas Chromatography and Lipids- A Practical Guide, The Oily Press, UK.

David, P. (1970) The Chemical Analysis of Food. $6^{\text {th }}$ ed. J. A Churchill, London, 
Gerpen, J.V. (2004): Biodiesel production Technologies Paper presentation, Department of biological and Agric Engineering, University of Idaho. U.S.A. Nov. 2004. p. 2.

Gerpen, J.V.; Scheuks, B.; Pruszko, K., Clement, D. Knothe, G.; (2002-2004): biodiesel production Technology: National Renewable Energy Laboratory, (NREL), Batwee, U.S.A. Technical Report (Aug 2002Jan 2004) P. 15-12, 23, 22-29).

Ibiyemi, S.A.; Fadipe, V.O. Akinremi, O.O. Bako S.S; (2002). Variation in Oil Composition of Thevetia Peruviana (Yallow Oleander) Fruits Seeds. J. Appl. Sci. Environ Mgt. 6 (2) 61-65.

Ibiyemi, S.A. Oluwaniyi, O.O.: (2003): Efficacy of catalysts in Batch esterification of the Fatty acids of Thevetia peruviana seed oil J. Appl. Sci. Environmental Mgt. $7(1) 15-17$

Klopfenstein,W.E.;J.Am oil Chem.Soc.1985,62, p10291031.

Kurdiana, D.; Saka, S. (2004): Biodiesel Fuel for diesel fuel substitute prepared by a catalyst-free super critical methanol. Grad School of energy Science, Kyoto University Kyoto 606-8501, Japan.
Kinast, J. A.(2003) Production of Biodiesels from Multiple Feedstocks and Properties of Biodiesels and Biodiesel/Diesel Blends, Final Report, National Renewable Energy Laboratory, Colorado, USA.

Manuel, J. (2007) Battle of the Biofuels, Environmental Health Perspectives, Institute of Environmental Health Sciences, USA. 2(115).

McCabe, W. L., Smith, J. C. and Harriott, P. C. (1987) Unit Operations in Chemical Engineering, $4^{\text {th }} \mathrm{Ed}$, Mc GrawHill Book Company, New York, pp 529-557.

Schmidt, C. W. (2007) Biodiesel: Cultivating Alternative Fuels, Environmental Health Perspectives, Institute of Environmental Health Sciences, USA. 2(115).

Vairavan, K., Thukkaiyannau, P., Paramathma, M., Venkatachalam, P. and Sampathrajan, A. (2010) Biofuels Crops: Cultivation and Management, Jatropha, Sweet sorghum and Sugarbeet, Agrobios (India), Jodhpur, India, pp 3-9, 68-92.

Worldwatch Institute (2008) Biofuels for Transport: Global Potentials and Implications for Sustainable Energy and Agriculture, Earthscan Publisher, London, pp 3-96 